\title{
減圧プラズマ溶射 $\mathrm{MCrAlY}$ 合金皮膜の機械的特性 ${ }^{\dagger}$

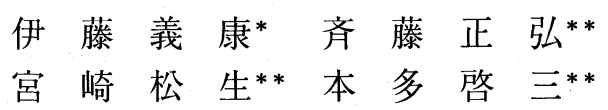

\author{
Mechanical Properties of Low-Pressure-Plasma Sprayed \\ MCrAlY Coatings
}

by

\author{
Yoshiyasu IтоH*, Masahiro SAItoH**, Matsuo MiYAZAKI** \\ and Keizo HondA**
}

\begin{abstract}
The low-pressure-plasma spray (LPPS) process is used to overlay coatings of MCrAlY alloy for protection against high temperature corrosion and oxidation. This coating process has been found to be very effective for gas turbine components. However, mechanical properties of LPPS MCrAlY alloy, which have an important effect on coating life, have not always been clarified. Five kinds of freestanding MCrAlY specimens (CoCrAlY, CoNiCrAlY, CoNiCrAlY + Ta, NiCrAlY, NiCoCrAlY) were machined from the thick LPPS coatings. Also, the heat treated MCrAlY specimens $(1393 \mathrm{~K}, 2 \mathrm{~h}, \mathrm{Ar}$ atmosphere) were used in experiments. The Vickers hardness, Young's modulus, Poisson's ratio and four point bending strength of the LPPS MCrAlY alloy were measured at room temperature in comparison with a nickel-base super-alloy, IN738LC. The experimental results suggest that the volume percentage of precipitated aluminum composite in the LPPS MCrAlY alloy has an important effect on the mechanical properties. Namely, there is a tendency that the Vickers hardness and Young's modulus increase with increasing the volume percentage of aluminum composite, and conversely the bending strength decreases with increasing the volume percentage of aluminum composite.
\end{abstract}

Key words : Low-pressure-plasma spray, MCrAlY alloy, Coating, Bending strength, Young's modulus, Hardness

\section{1 緒言}

発電用ガスタービンでは, 作動温度の高温化が発電 効率の向上に直接つながることから，従来より継続的 に高温化を目指した研究開発が進められている. 特に, ガスタービンの入口温度が $1300 \mathrm{~K}$ を越える現状にお いては, 高温強度に優れたタービン翼材料の開発と共 に，高温耐食コーティング技術の開発が必須課題と なっている. 現在, ガスタービン動翼の高温酎食コー ティングには，減圧プラズマ溶射プロセスが実用化さ れており高温での耐酸化性，耐食性に優れた種々の MCrAlY（M は Ni，Co，Fe）合金が開発され，コ ーティング材料として用いられている.

ところで，隇圧プラズマ溶射プロセスにより形成さ れた MCrAlY 合金皮膜の耐食，耐酸化特性について は, 当然のことながら数多くの研究が従来より行われ てきている. しかしながら, 高温耐食コーティング翼 の寿命特性は, 皮膜の耐食, 耐酸化特性以外に, 皮膜 に生じる熱応力や皮膜の材料強度などの機械的特性に よっても，大きな影響を受けることが示されている。
すなわち，高温耐食コーティング皮膜の機械的特性の 把握は重要な課題と考えられるが，皮膜試験片の製作 と評価試験自体が困難なこともあり, CoCrAl Y Y , NiCoCrAlY 年など一部の皮膜材料について検討されて いるが，必ずしも系統的には明らかにされていないの が現状である。

以上より, 本研究では代表的な $\mathrm{Co}$ 基, $\mathrm{Ni}$ 基の数 種類の MCrAlY コーティング皮膜について, ヤン グ率, ポアソン比，曲げ強度などの機械的特性を明 らかにし，比較を行うことを目的とする．さらに， MCrAlY コーティング皮膜の曲げ破壊挙動について 考察を加える.

\section{2 実験}

実験に供した皮膜原料は，市販の MCrAIY 合金粉 末の中から, CoCrAlY, CoNiCrAlY, CoNiCrAlY $+\mathrm{Ta}$, NiCrAIY, NiCoCrAlY の 5 種類を選択した. Table Iには，使用した溶射粉末の化学組成と粉末粒 度をまとめて示す。試験片は減圧プラズマ溶射装置 (Plasma Technik A-2000V VPS System) を用い,

$\dagger \quad$ 原稿受理 平成 5 年 7 月 2 日 Received July 2,1993

* 正 会 員 (株)東芝重電技術研究所 ₹230 横浜市鶴見区末広町, Heavy Apparatus Eng. Lab., Toshiba Co., Tsurumi-ku, Yokohama, 230

** (株)東芝重電技術研究所 T230 横浜市鶴見区末広町, Heavy Apparatus Eng. Lab., Toshiba Co., Tsurumi-ku, Yokohama, 230 
Table I. Chemical compositions of spraying powders used.

\begin{tabular}{l|c|c|c|c|c|c}
\hline \multirow{2}{*}{ Materials } & \multicolumn{5}{|c}{ Chemical compositions (wt. \%) } \\
\cline { 2 - 7 } & $\mathrm{Co}$ & $\mathrm{Ni}$ & $\mathrm{Cr}$ & $\mathrm{Al}$ & $\mathrm{Y}$ & $\mathrm{Ta}$ \\
\hline $\begin{array}{c}\text { CoCrAlY } \\
-400 \text { mesh }\end{array}$ & Bal. & $<0.10$ & 28.9 & 6.15 & 0.28 & - \\
\hline $\begin{array}{c}\text { CoNiCrAlY } \\
-400 \text { mesh }\end{array}$ & Bal. & 32.08 & 21.22 & 8.33 & 0.39 & - \\
\hline $\begin{array}{c}\text { CoNiCrAlY }+\mathrm{Ta} \\
-400 \text { mesh }\end{array}$ & Bal. & 9.7 & 24.6 & 7.0 & 0.48 & 5.5 \\
\hline $\begin{array}{c}\text { NiCrAlY } \\
-400 \text { mesh }\end{array}$ & - & $\mathrm{Bal}$. & 31.45 & 11.55 & 0.825 & - \\
\hline $\begin{array}{c}\text { NiCoCrAlY } \\
-325 \text { mesh }\end{array}$ & 23.23 & $\mathrm{Bal.}$ & 16.94 & 12.47 & 0.49 & - \\
\hline
\end{tabular}

予熱温度 $843 \mathrm{~K}$, 電圧 $64 \mathrm{~V}$, 電流 $685 \mathrm{~A}, \mathrm{Ar}$ 雲囲気 6 $\mathrm{kPa}$, 溶射距離 $270 \mathrm{~mm}$ で形成した厚さ $2 \mathrm{~mm}$ 程度の 皮膜から, 機械加工により切り出して作製した. また, 試験片は溶射のまま（As sprayed）の場合と, 1393K, $2 \mathrm{~h}$, Ar 冷却の拡散熱処理を施した溶射皮膜の場合 について切出し加工をし, 特性比較の実験に供した。

一般に，この拡散熱処理は減圧プラズマ溶射によって 基材が受けた熱的ダメージを回復させると共に，基材 と皮膜との密着強度, 皮膜自体の特性改善を目的に実 施される. Table II には比較のため実験に供した IN738LC 精密鋳造材料の化学組成と機械的性質につ いてまとめて示す。

実験は $50 \times 5 \times 1.5 \mathrm{~mm} の$ 四点曲げ試験片を用いて,
Table II. Chemical compositions and mechanical properties of IN738LC.

\begin{tabular}{c|c|c|c|c|c|c|c|c|c}
\hline \multirow{2}{*}{ Material } & \multicolumn{8}{c}{ Chemical compositions (wt. \%) } \\
\cline { 2 - 8 } & $\mathrm{Ni}$ & $\mathrm{Cr}$ & $\mathrm{W}$ & $\mathrm{Mo}$ & $\mathrm{Co}$ & $\mathrm{Al}$ & $\mathrm{Ti}$ & $\mathrm{Nb}$ & $\mathrm{Ta}$ \\
\hline IN738LC & Bal. & 15.8 & 2.46 & 1.78 & 8.11 & 3.45 & 3.60 & 0.92 & 1.92 \\
\hline \multicolumn{1}{c}{ Tensile test at room temperature } \\
\hline 0.2\% proof stress & Tensile strength & Elongation & \multicolumn{3}{|c}{ Hardness (HRC) } \\
\hline 936 MPa & \multicolumn{3}{|c|}{$1149 \mathrm{MPa}$} & $7 \%$ & \multicolumn{3}{|c}{41.5} \\
\hline
\end{tabular}

Heat treatment ; $1393 \mathrm{~K} \times 2 \mathrm{~h} \mathrm{Ar}$ cooled,

$1116 \mathrm{~K} \times 24 \mathrm{~h} \mathrm{Ar}$ cooled.

室温に打いてアルキメデス法 (水浸法)により密度测 定を実施し, 試験片端部で硬さ測定を行った後に, 才 ートグラフ (島津製作所製) を用い，变位速度 0.1 $\mathrm{mm} / \mathrm{min}$. で曲げ強度の測定を行った. また, 四点曲 げ試験でひずみゲージ法により，ヤング率，ポアソン 比の測定も行った.

\section{3 皮膜の機械的特性}

\section{$3 \cdot 1$ 皮膜組織と密度, 硬さ}

Fig. 1 には，減圧プラズマ溶射プロセスにより形成 した CoCrAlY 合金皮膜の, As sprayed の場合と拡 散熱処理を施した場合の断面組織写真の一例を示す. 図から明らかなように，大気中プラズマ溶射プロセス の場合と比べて，滅圧プラズマ溶射プロセスで形成し た皮膜は，As sprayed の場合においても十分ち密で あることが分る。 また，As sprayed の場合の皮膜組

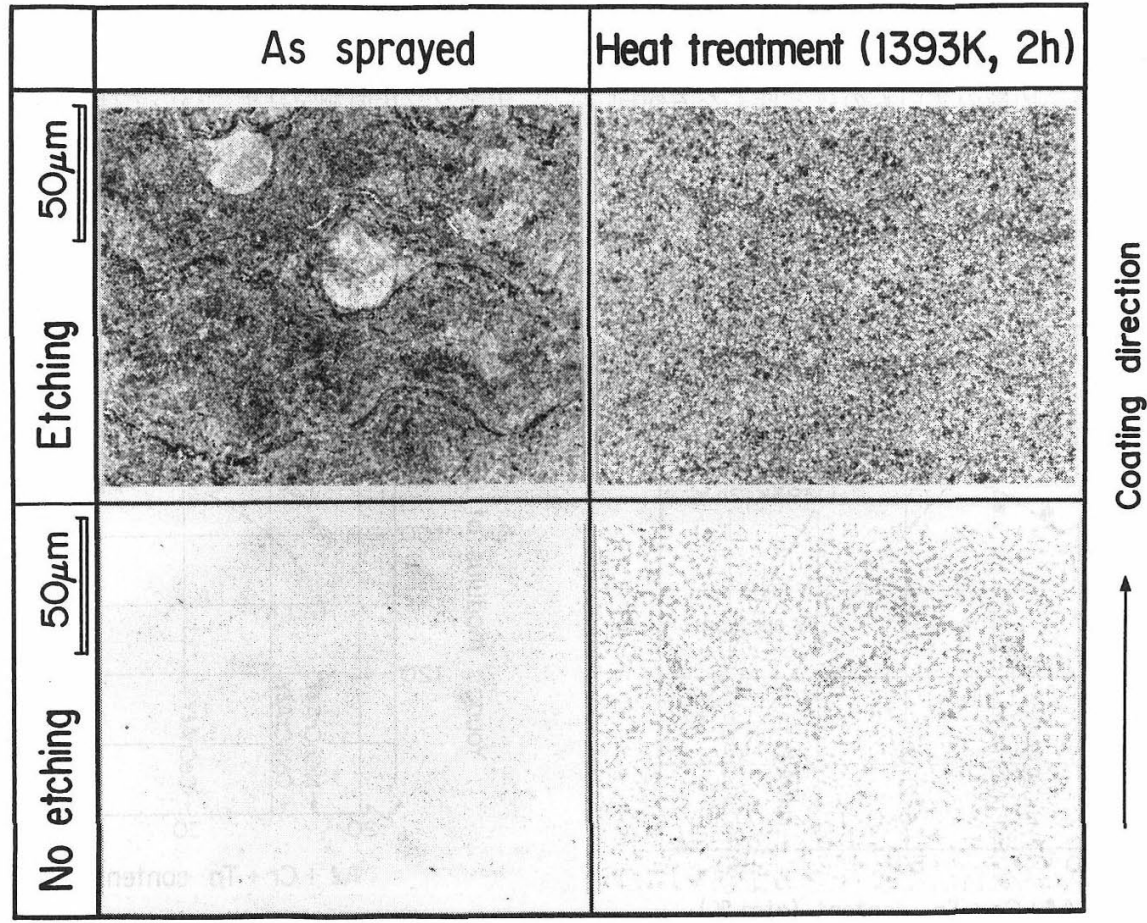

Fig. 1. Microstructures of low-pressure-plasma-deposited CoCrAlY coating. 


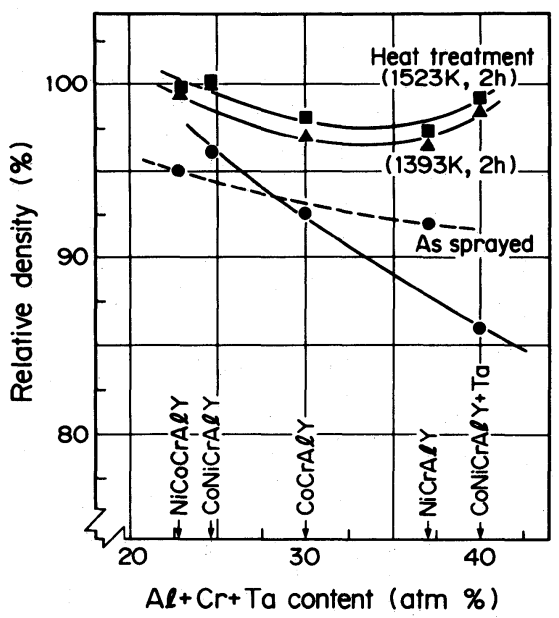

Fig. 2. Relative density of LPPS MCrAIY alloy.

織には，未溶融粒子と共に積層模様が明瞭に認められ るが，拡散熱処理を施すことにより方向性のない均質 な組織に改善されることも明らかである，実験に供し た他の MCrAlY 合金皮膜についても，未溶融粒子， 気孔の多少に差は認められるものの，ほぼ同様の様相 を示した

Fig. 2 には，皮膜の相対密度を測定した結果につい てまとめて示す．ただし，各 MCrAlY 合金皮膜の真 密度は，溶射粉末を用いてピクノメー夕法（JIS M8717）により測定した. 図から明らかなように, As sprayed の溶射皮膜の相対密度は，Co 基の MCrAlY 合金皮膜, Ni 基の MCrAlY 合金皮膜共に, $\mathrm{Al}, \mathrm{Cr}, \mathrm{Ta}$ の添加量の多いものほど低くなる傾向 を示す。また，1393K の拡散熱処理を施すことによ り，いずれの MCrAlY 合金皮膜も $95 \%$ 以上の相対 密度を示すことが分かる．図中には，1523K の拡散 熱処理を施した場合の結果も示すが，各 MCrAlY 合

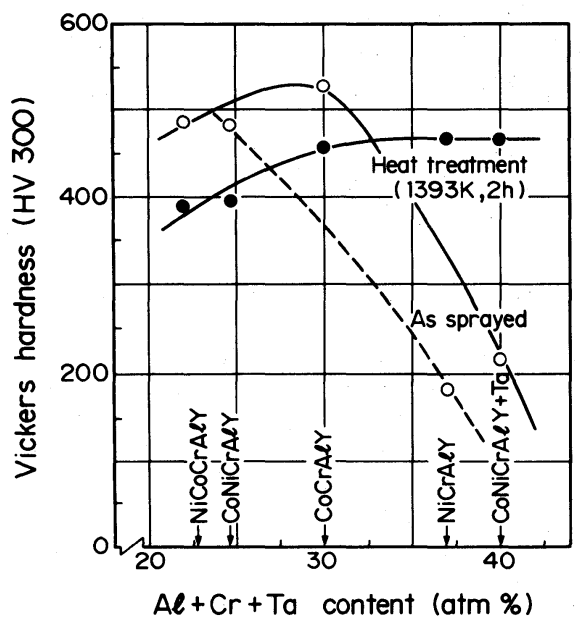

Fig. 3. Vickers hardness of LPPS MCrAlY alloy.
金皮膜ともに拡散熱処理温度を上げることで，相対密 度も上昇する傾向にあることが分かる.

一方，Fig. 3 に示すように，As sprayed の状態で 十分にち密化している NiCoCrAlY, CoNiCrAlY, CoCrAlY は，拡散熱処理を施すことにより皮膜硬さ が低下する傾向を示す。これは溶射時の急冷凝固によ り，As sprayed 皮膜の組織が比較的細かいのに対し て，拡散熱処理を施すと皮膜組織が粗大化するためと 考えられる，逆に，As sprayed でち密化が十分でな い NiCrAlY，CoNiCrAlY + Ta は，拡散熱処理によ り密度が向上し，顕著な硬さ上昇を示す．また，皮膜 硬さに及ぼす $\mathrm{Al}+\mathrm{Cr}+\mathrm{Ta}$ 添加量の影響については, その増加が MCrAlY 合金皮膜中の金属間化合物の形 成量を増すと考えられるため, $\mathrm{Al}+\mathrm{Cr}+\mathrm{Ta}$ 量の増 加するほど，硬さは高くなる傾向を示すことが分かる.

$3 \cdot 2$ ヤング率，ポアソン比

各種 MCrAlY 合金皮膜の室温におけるヤング率， ポアソン比の測定結果を Fig. 4, 5 にまとめて示す. 図から明らかなように, $\mathrm{Co}$ 基， $\mathrm{Ni}$ 基の $\mathrm{MCrAl}$ 合金 皮膜は共に拡散熱処理を施して皮膜がち密化すると， ヤング率は高くなる傾向を示す。このヤング率が高く なる傾向は，いずれの MCrAlY 合金皮膜でも同程度 に生じている。また，As sprayed，拡散熱処理，い ずれの場合についても，MCrAlY 合金皮膜中の $\mathrm{Al}$ $+\mathrm{Cr}+\mathrm{Ta}$ 添加量が増すと, ヤング率は高くなる傾 向を示すようである. しかし，Fig. 3 で示した硬さの 測定結果と同様に, $\mathrm{Al}+\mathrm{Cr}+\mathrm{Ta}>30 \mathrm{~atm} \%$ 以上で はヤング率の上昇は認められない.

ポアソン比の測定結果については，Fig. 5 から明ら かなように, $\mathrm{Co}$ 基, $\mathrm{Ni}$ 基の $\mathrm{MCrAlY}$ 合金皮膜間で 顕著な差は認められない。また, $\mathrm{Al}+\mathrm{Cr}+\mathrm{Ta}$ 添加

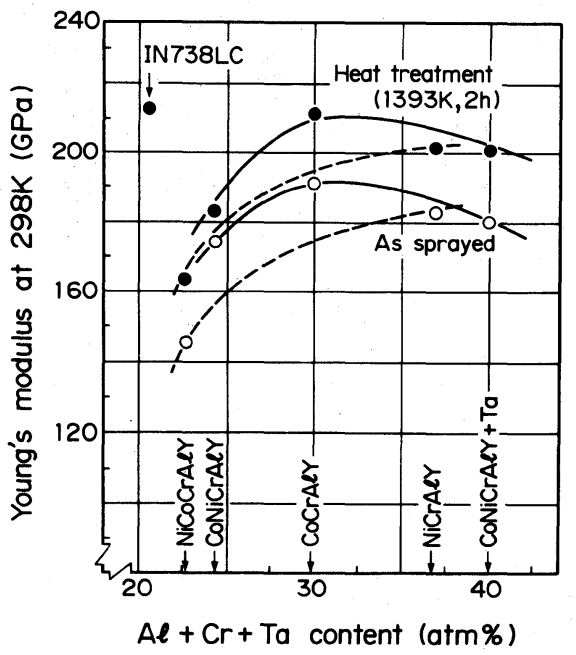

Fig. 4. Young's modulus at $298 \mathrm{~K}$ of LPPS MCrAlY alloy. 


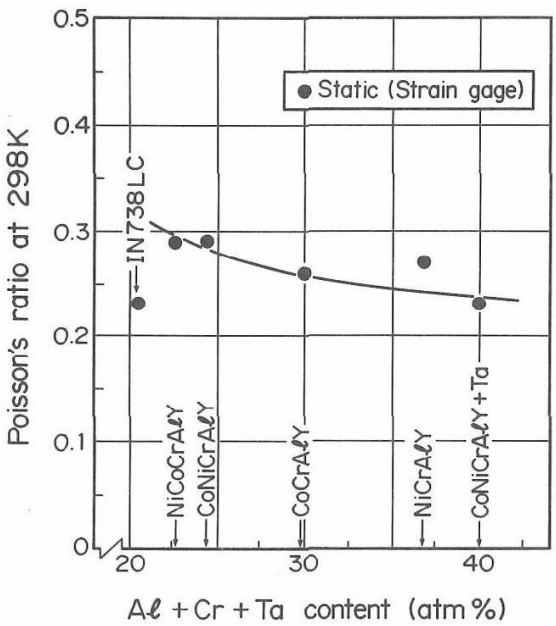

Fig. 5. Poisson's ratio at $298 \mathrm{~K}$ of LPPS MCrAIY alloy.

量の效果についても，0.3 から 0.25 程度まで若千低下 する傾向も認められるが，顕著な影響は無いようであ る.

一方，図中には比較のためガスタービン翼材として 良く知られている IN738LC 素材について, MCrAlY 合金皮膜の場合と同様の方法で測定したヤング率とポ アソン比の結果を示す。本研究の範囲内では Co 基, $\mathrm{Ni}$ 基の MCrAlY 合金皮膜共にヤング率は IN738LC

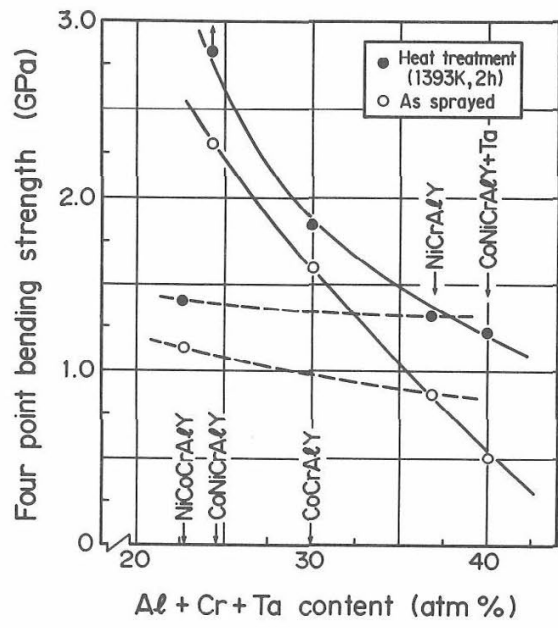

Fig. 6. Four point bending strength of LPPS MCrAlY alloy.

素材よりも低目の值を示し，ポアソン比については高 目の值を示す傾向が認められる。

$3 \cdot 3$ 四点曲げ強度

Fig. 6 には，各 MCrAlY 合金皮膜の室温に掞ける 四点曲げ強度の試験結果をまとめて示す。実験におい ては, CoNiCrAlY 合金皮膜のみが最高荷重点を示し て分離破壞には至らなかったが，他の MCrAlY 合金 皮膜についてはいずれも荷重一たわみ関係がほぼ線形

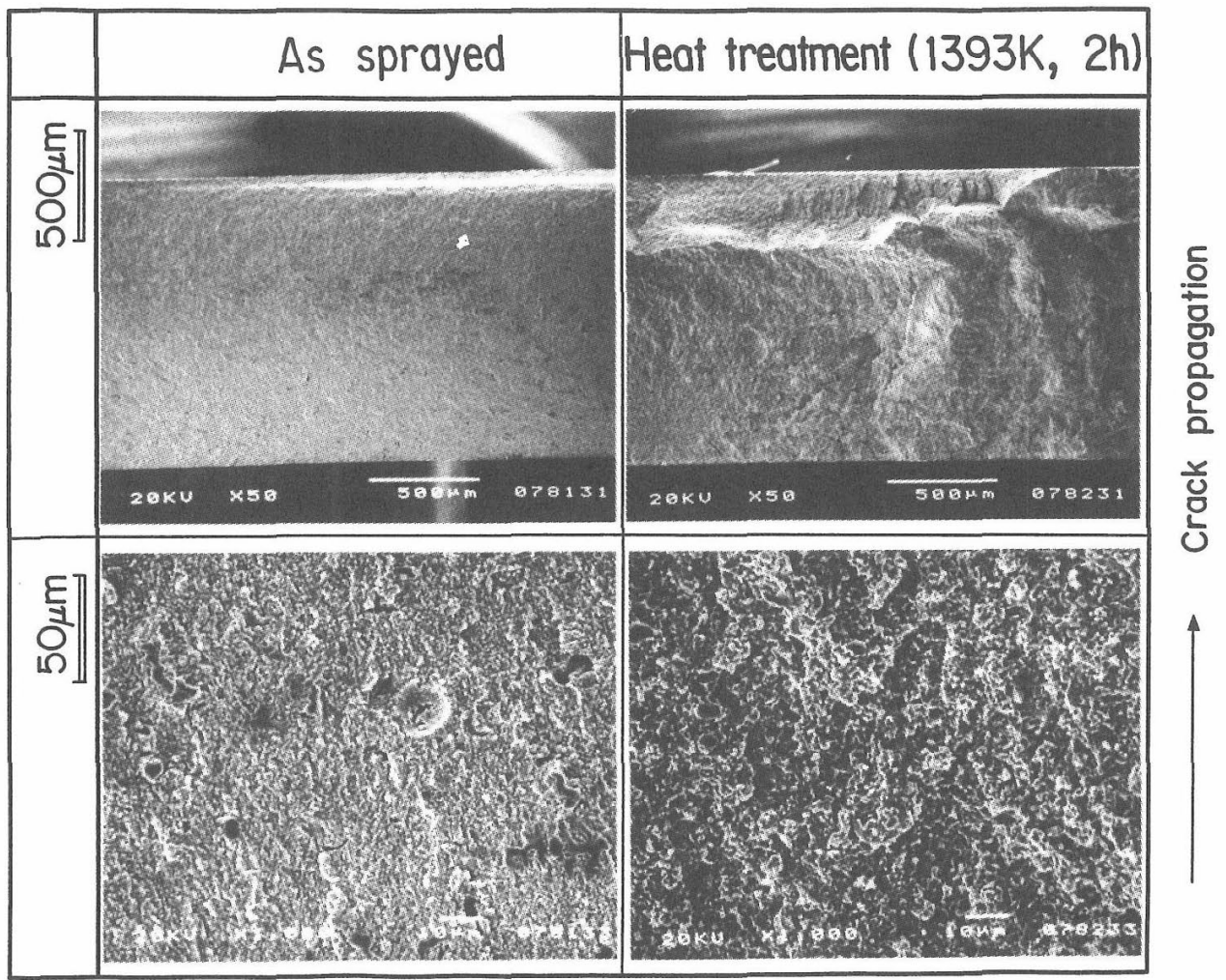

Fig. 7. Fracture surface morphologies of LPPS CoNiCrAlY + Ta alloy. 
の状態で破壞に至った。したがって図には，CONi CrAlY 合金皮膜の場合には最高荷重点，他の $\mathrm{MCr}$ AIY 合金皮膜については破壞荷重から曲げ強度を求 めて示した．実験結果から明らかなように, Co 基, $\mathrm{Ni}$ 基の MCrAlY 合金皮膜は共に拡散熱処理を施して 皮膜がち密化すると，曲げ強度は高くなる傾向を示す。 この傾向に関して MCrAIY 合金皮膜の種類による差 は顕著ではない，また，Co 基， Ni 基の MCrAlY 合 金皮膜との間で，曲げ強度には顕著な差が認められる。 すなわち, $\mathrm{Al}+\mathrm{Cr}+\mathrm{Ta}$ の添加量が増加するほど, 四点曲げ強度は低下寸る傾向にある。この傾向は $\mathrm{Al}$ $+\mathrm{Cr}+\mathrm{Ta}$ 添加量の増加が, MCrAlY 合金皮膜中に じん性の低い金属間化合物の形成量を増すためと考元 られる。Co 基の MCrAlY 合金において，この强度 低下傾向は顕著である。特に CoNiCrAlY 合金皮膜 は高い強度を示すが，さらに拡散熱処理を施すことに より，顕著な強度と延性の改善が認められた。しかし， $\mathrm{Ni}$ 基の $\mathrm{MCr} \mathrm{AlY}$ 合金皮膜では, $\mathrm{Al}+\mathrm{Cr}+\mathrm{Ta}$ 添加 量の影響は小さい.

Fig. 7 には一例として CoNiCrAlY+Ta 合金皮膜 の破面 SEM 観察結果を示す。As sprayed の場合に はマクロな破面が極めて平坦であることが分かる。ま た，ミクロに観察すると破面の所々に最大数十 $\mu \mathrm{m}$ 程
度の大きさの不規則形状の気孔や，球状の未溶融粒子 の形跡が認められる。しかしながら，拡散熱処理を施 すことによりマクロな破面の凹凸が顕著となり，ミク 口に観察しても明暸な欠陷の存在が認められない. 破 面形態については，観察ができなかった CoNiCrAlY 合金皮膜を除き, 他の MCrAlY 合金皮膜についても ほぼ同様であった。すなわち，As sprayed 皮膜の強 度が低い原因は，皮膜中の気孔や，未溶融粒子の存在 にあるということができる。

\section{4 考察}

前章で示したように, MCrAlY 合金皮膜の機械的 特性は， $\mathrm{Al}+\mathrm{Cr}+\mathrm{Ta}$ 添加量に依存することが明ら かである，保護性酸化皮膜の生成元素である $\mathrm{Al}, \mathrm{Cr}$, あるいは保護性酸化皮膜の補強維持機能を有すると考 えられる Ta の添化量の増大は，MCrAlY 合金皮膜 の耐酸化性，耐食性の向上に有効であることが知られ ている。しかし， $\mathrm{Al} ， \mathrm{Cr}$ 添加量の増大は，一般に皮 膜延性の低下を生じるといわれている。

Fig. 8 には, 一例として CoNiCrAlY, NiCrAlY 合金皮膜組織を SEMにより観察した結果を示す．図 中には金属間化合物相の区別を行うために，Al 成 分の EPMA 線分析結果を併せて示す。従来より

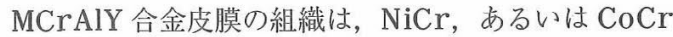

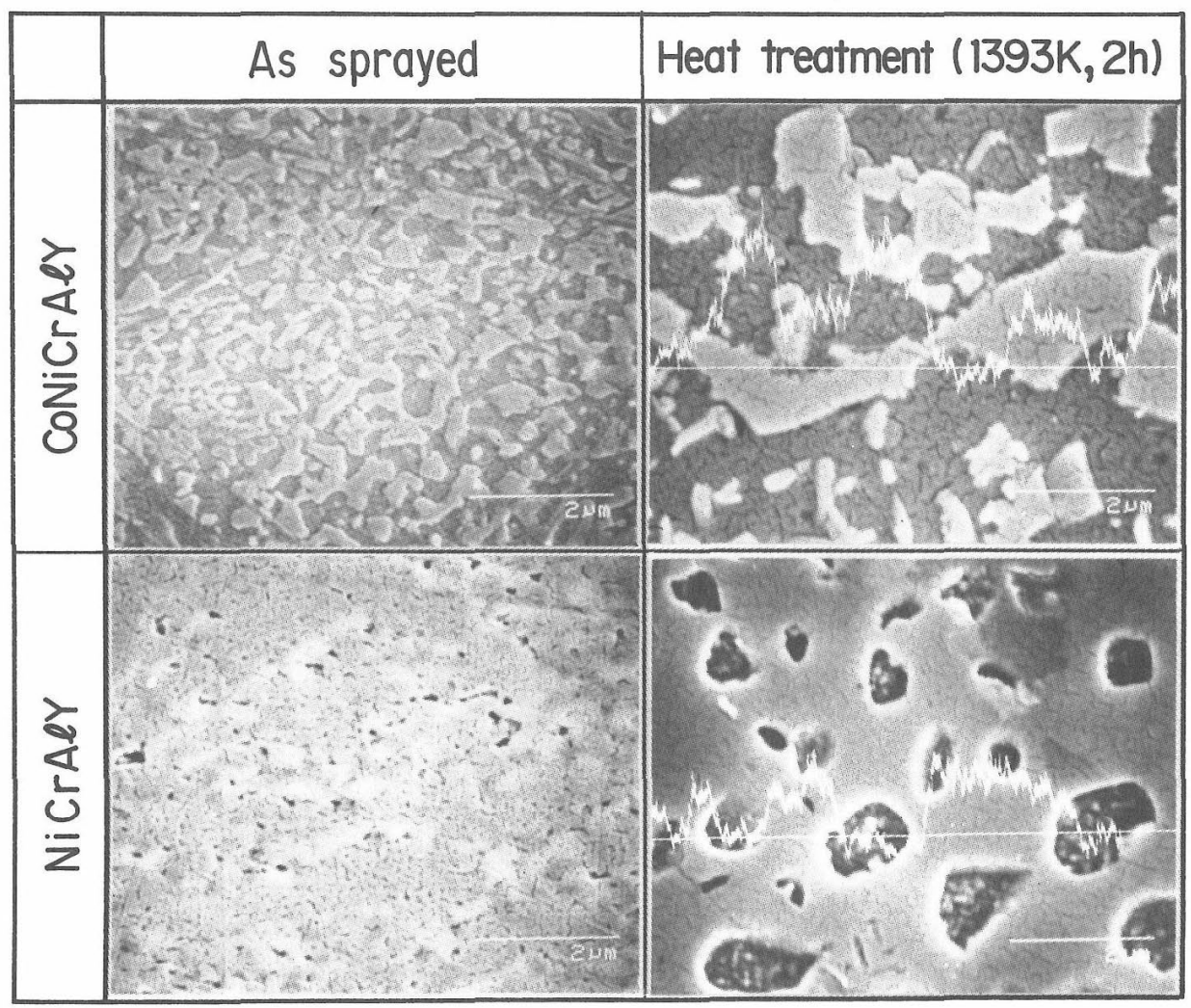

Fig. 8. Microstructures of LPPS CoNiCrAlY and NiCrAlY alloy. 

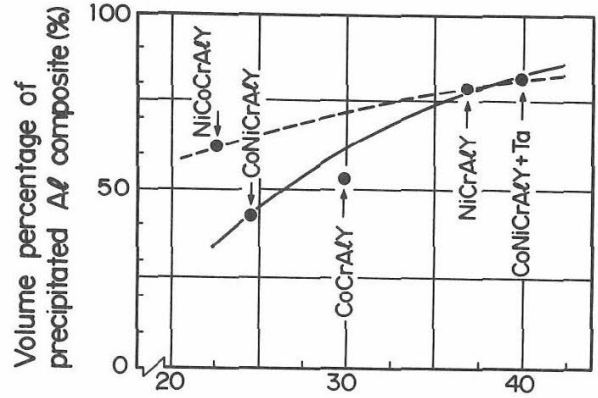

$\mathrm{Al}+\mathrm{Cr}+\mathrm{Ta}$ content ( $\mathrm{atm} \%)$

Fig. 9. Volume percentage of precipitated $\mathrm{Al}$ composite for various MCrAlY alloy.

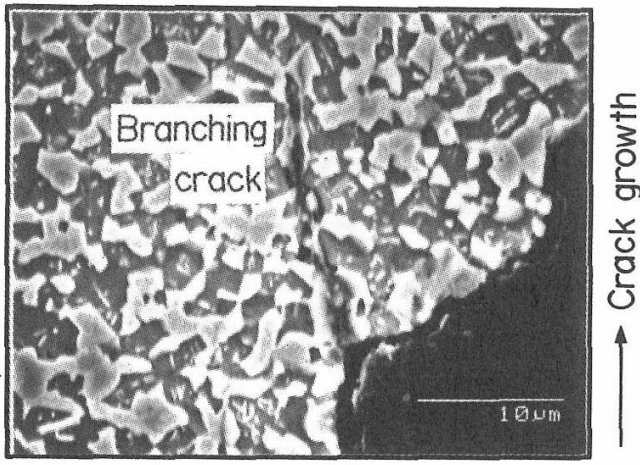

$1393 \mathrm{~K}, 2 \mathrm{~h}$

Fig. 10. Microstructures near fracture surface and branching crack.

の固溶体マトリックスの中に NiAl 系，あるいは CoAl 系の金属間化合物が析出した 2 種類以上の相よ り構成されていることが知られている。図から明らか なように, As sprayed の場合には，溶射過程におい て溶融粒子が急冷されて皮膜が形成されるために，組 織は比較的微細であることが分る。しかし，拡散熱処 理を施すことにより，微細に析出した金属間化合物相 は凝集し粗大化する傾向にある。また, CoNiCrAlY 合金皮膜の場合には固溶体マトリックスと析出した金 属間化合物の体積比は，ほぼ同程度であり，金属間化 合物はばらばらに存在していることが分かる。しかし， NiCrAIY 合金皮膜の場合には金属間化合物の体積比 が約 $80 \%$ と高く, 金属間化合物相が連結した構造に なっていることが分かる。

Fig. 9 には拡散熱処理を施した各 MCrAlY 合金皮 膜について, Fig. 7 で示したようなミクロ組織観察結 果加求めた $\mathrm{Al}$ 系金属間化合物析出相の体積比率を 示す．得られた結果はFig. 3 の硬さ，Fig. 4 のヤング
率，Fig. 6 に示した曲げ強度と非常に良い傾向の一致 を示していることが分る，すなわち，Al 系金属間化 合物の体積比の多い MCrAIY 合金皮膜ほど，硬さ， ヤング率が高く，曲げ強度の低下が著しい，特に， $\mathrm{Ni}$ 基の MCrAlY 合金皮膜は, Co 基の MCrAlY 合 金皮膜よりも高ヤング率，低強度となるのは，金属間 化合物の体積比が大きいためと考えられる，曲げ試験 老行った CoCrAlY 合金皮膜の破断部組織の観察結 果をFig. 10 に示す. 図中には分岐した停止き裂も観 察されるが，き裂はじん性の低い金属間化合物相を連 ねるように進展している様子が認められる。

\section{5 結論}

(1) $\mathrm{Al}+\mathrm{Cr}+\mathrm{Ta}$ 添加量の多い MCrAlY 合金皮膜 ほど，減圧プラズマ溶射時に気孔や未溶融粒子が残り 易く，皮膜の密度や硬さが低くなる傾向を示す．しか し 1393K，2 h の拡散熱処理を施すことにより，皮膜 は密度 $95 \%$ 以上に十分ち密化でき，硬さむ高くなる 傾向を示す。

(2) As sprayed，拡散熱処理に関係なく, $\mathrm{Al}+\mathrm{Cr}$ $+\mathrm{Ta}$ 添加量の多い MCrAlY 合金皮膜ほど, ヤング 率は上昇する傾向が認められる。しかし, ポアソン比 は皮膜材料による顕著な差は認められず，0.25〜0.3 である。

（3） Co 基の MCrAlY 合金皮膜では, $\mathrm{Al}+\mathrm{Cr}$ $+\mathrm{Ta}$ 添加量の多いほど四点曲げ強度は顕著に低下す る.しかし， Ni 基の MCrAlY 合金皮膜ではほとんど 影響を受けない。また，拡散熱処理により，皮膜の曲 げ強度は改善学れる。

（4） MCrAlY 合金皮膜のヤング率，曲げ強度は皮 膜中の $\mathrm{Al}$ 系金属間化合物相の体積比率と良い傾向の 一致を示す。すなわち，金属間化合物相の体積比率が 高いほどヤング率は高く, 曲げ強度は低くなる。

\section{参 考 文 献}

1 ) 伊藤義康, 斎藤正弘, 機械の研究，44-2，257（1992）; 44-3, 369 (1992).

2 ) 吉岡洋明, 斎藤大藏, 村上 格, 藤山一成, 岡部永年, 材料, 41，1724 (1992).

3 ) R. W. Smith, Thin Solid Films, 84, 59 (1981).

4) M. I. Wood, Surface and Coating Technology, 39/40, 29 (1989).

5 ) K. Schneider and H. W. Grunling, Thin Solid Films, 107, 395 (1983).

6 ) J. M. Veys, A. Riviere, R. Mevrel, 1st Plasma-Technik-Symposium, 2, 115 (1988). 